\title{
EXPERIMENTAL STUDY ON A PULSATION-ENHANCED HEAT TRANSFER DEVICE
}

CLiu Z., ORCID: 0000-0002-7603-1060, Ogarev Mordovia State University, Jiangsu University of Science and Technology, Zhenjiang, China, liu_zuncheng@163.com

CLevtsev A., SPIN-code: 7896-7312, Dr. habil., Ogarev Mordovia State University,

Saransk, Russia, levtzevap@mail.ru

(CZhou Y., ORCID: 0000-0002-4530-5137, Ogarev Mordovia State University, Jiangsu University of Science and Technology, Zhenjiang, China, 1328832703@qq.com

\section{РАСШИРЕНИЕ ТЕПЛОВОЙ ПЕРЕДАЧИ ТЕПЛООБМЕННОГО ОБОРУДОВАНИЯ ИМПУЛЬСОМ ВОЗДУШНОГО ПОТОКА}

(СЛю Ц., ORCID: 0000-0002-7603-1060, Национальный исследовательский Мордовский государственный университет им. Н. П. Огарева, Цзянсуский университет науки и техники, 2. Чжэньизян, Китай, liu_zuncheng@163.com

(СЛевцев А. П., SPIN-код: 7896-7312, д-р техн. наук, Национальный исследовательский Мордовский государственный университет им. Н. П. Огарева, г. Саранск, Россия, levtzevap@mail.ru

(сЧжноу И., ORCID: 0000-0002-4530-5137, Наџиональный исследовательский Мордовский государственный университет им. Н. П. Огарева, Цзянсуский университет науки и техники, г. Чжэньизян, Китай, 1328832703@qq.com

Abstract. The pulsation-enhanced heat transfer technology is introduced, and a volume coil heat exchanger is designed. A pulsation valve is installed at the heat exchanger outlet of the heat exchanger to pulsate the heat medium, and the same heat exchanger is subjected to pulsation and non-pulsation heat transfer tests. Based on the experiments, combined with the theory of pulsationenhanced heat transfer technology, heat transfer capacity, heat flow, and convective heat transfer coefficient coefficients, the effective temperature difference, heat flow, and convective heat transfer coefficient of the heat exchanger at different pulse frequencies are analyzed. The relationship between the pulsation frequency of the heat transfer effect of the heat exchanger is obtained. The test results show that the heat exchanger has higher heat exchange efficiency when there is pulsation under the test conditions.

Аннотащия. Рассмотрена технология импульсной подачи теплоносителя и разработан змеевиковый теплообменник. На выходе из теплообменника установлен ударный клапан для создания импульсного режима течения теплоносителя, также данный теплообменник подвергался испытаниям при импульсной и традиционной подаче рабочей среды. На основе проведенных экспериментов в сочетании с теорией импульсной технологии теплообмена проанализированы коэффициенты теплоемкости, теплового потока и коэффициента конвективной теплоотдачи, эффективная разница температур, тепловой поток и коэффициент конвективной теплоотдачи теплообменника при различных частотах импульсов. Получена зависимость частоты пульсаций от теплопередающего эффекта теплообменника. Результаты испытаний показывают, что теплообменник имеет более высокую эффективность теплообмена при импульсной подаче теплоносителя. 
Keywords: pulsating generator, pulsating flow, frequency, heat transfer.

Ключевые слова: ударный узел, пульсирующий поток, частота, теплопередача.

\section{Research Background and Theoretical Research}

Energy is an important material basis for human survival and development, and a driving force for various economic activities. At present, energy, materials and information are called the three pillars of the prosperity and development of modern society. Since the outbreak of the global oil crisis in the early 1970s, energy-centric environmental, ecological and socio-economic issues have intensified. The countries of the world are fully aware of the importance of energy conservation, and the rational use of energy has become a core issue in the healthy development of industry. In practical industrial production, the most common device for enhancing heat transfer technology is a heat exchanger. The research on heat transfer enhancement technology of heat exchangers mainly focuses on two directions. First, the development of new heat exchangers, followed by the strengthening of traditional heat exchangers.

Enhanced heat transfer technology is an advanced technology developed in the 1960s and 1970s to improve heat transfer performance. Its main task is to increase the heat transfer rate, achieve the specified heat transfer with more economical equipment, or use more efficient cooling methods to protect the safe operation of high temperature components, or use higher thermal efficiency to achieve reasonable energy utilization [1] . The annual data on the number of enhanced heat transfer literatures in the United States by Professor Bergles, USA [2], intuitively reflects the rapid development of enhanced heat transfer research. Enhanced technology can be divided into passive and active technologies or passive and active technologies based on whether additional power is needed [3-6].

The enhanced heat transfer technology aims to improve heat transfer performance, improve heat transfer efficiency, achieve the most economical equipment to complete the transfer of the determined energy, and most effectively cool and protect the high-temperature components for safe operation and achieve efficient use of energy. Ortega [7], staats [8], Yan [9], Mahmoudi [10], Defraeye [11], CHangt [12], Guo [13] and many other scholars used experimental and numerical analysis methods to study how to achieve reinforcement. Heat transfer and how to optimize the convective heat transfer problem have yielded many valuable research results.

It is well known that the heat transfer surface enhances the disturbance of the surrounding fluid by vibration and destroys the boundary layer of the wall to achieve enhanced heat transfer. Early research on vibration-enhanced heat transfer focused on enhanced heat transfer experiments based on forced vibration. The vibration modes used mainly include: (1) mechanical vibration or motor drive biasing device; (2) fluid flow induced vibration; (3) ultrasonic excitation vibration. With the rapid development of computer technology and numerical analysis methods, various numerical simulation methods have been used to study the heat transfer characteristics of heat transfer elements under forced vibration conditions.

There is a large amount of fluid pulsation in the heat exchanger. The pulsation frequency of the fluid ranges from $1 \mathrm{~Hz}$ to the ultrasonic frequency and has a certain degree of influence on heat transfer. In 1929, Richardson [14] applied a hot wire anemometer to measure the steady state and pulsation velocity of the tube and compare the theoretical values of the average velocity gradient within the tube. And measuring the value, found the "ring effect" of the pulsating flow rate, marking the beginning of the pulsating heat transfer study. Later, Uchida [15] and other theories deduced the velocity distribution of the pulse flow in the circular tube and the parallel plate channel, and obtained the analytical solution of the laminar flow velocity distribution in the circular tube and the parallel plate channel. Confirm that there is a "speed loop effect". Due to the "speed loop effect" of the reciprocating 
velocity distribution in the pulse stream, the flow velocity near the wall surface is greater than the flow velocity at the center of the tube, so that convective heat transfer can be enhanced by the pulse. In 1954, Havemaim [16] published a research paper entitled "Heat Transfer in Pulsating Flows" in the internationally renowned magazine "Nature", which attracted widespread attention from scholars in various countries on pulsating heat transfer. In the experiment, Havemaim studied the heat transfer performance under different parameters in detail. The experimental results show that the heat transfer performance varies with frequency, amplitude, waveform and Re number, $\mathrm{Nu}$ can be increased by $30 \%$; the limit frequency can improve heat transfer, and vice versa, heat transfer is weak; the limit frequency is waveform and Re number Function, as Re increases, the value will increase slowly; pressure amplitude and pressure are considered to be in the wave. The rate of change plays an important role in pulsating heat transfer. Bergles [17] experimentally studied the flow and heat transfer characteristics of pulsating flow in the 1960s, confirming that pulsating flow can enhance heat transfer. Subsequently, relevant scholars carried out a large number of theoretical analysis, numerical simulation, experimental testing and other work on the pulsating flow heat transfer problem, but the conclusions about its influence on heat transfer are still inconsistent. Wang et al. [18] studied the turbulent heat transfer problem of large velocity amplitude in the heat transfer tube under the boundary of the wall temperature by numerical simulation. The analysis shows that Womersley number plays a decisive role in flow and heat transfer; under the optimal Womersley number parameter, the heat transfer coefficient is the largest; large amplitude and reflow promote heat transfer; the flow state and heat transfer in the tube are mainly affected by the pulsation frequency and pulsation amplitude. The influence of the Reynolds number, the Prandtl number, and the form of the pulsating flow (square wave, sine); the position of the pulsation origin, the position of the upstream and downstream of the pulsating flow also affects the heat transfer characteristics. Elshafei et al. [19] also carried out related research in this field, indicating that the heat transfer performance is mainly affected by the pulsating flow frequency and the flow Reynolds number, and the influence of pulsating flow on heat transfer depends on the flow parameters, when $\operatorname{Re}=37100, \mathrm{f}=13.3$ When $\omega=0.5$, the heat transfer performance is increased by $9 \%$ compared with the steady-state flow condition; and when $\operatorname{Re}=13350, \mathrm{f}=42.5 \mathrm{~Hz}$, $\omega=4.4$, the heat transfer performance is reduced by $12 \%$.

\section{Experimental Research}

Installation of laboratory equipment includes assembly of structural components, such as: metal heat exchanger body; copper coil, $\varnothing 10 \mathrm{~mm}$; flange; rotary joint; electric engine; polypropylene water pipe, $\varnothing 25 \mathrm{~mm}$; influence node; liquid flow meter; thermocouple temperature sensor The drain valve is installed at the outlet of the pipe at the working environment; the impact node is installed in the network behind the energy flow converter, and its rotation is performed by the operation of the $12 \mathrm{~V}$ engine.

In this experiment, the cooling medium was cold water with an initial temperature of $20^{\circ} \mathrm{C}$, and the heating medium was hot water with a temperature of $79^{\circ} \mathrm{C}$. A total of two trials were designed. In the first group, control the flow rate to $0.2 \mathrm{~L} / \mathrm{s}$, change the frequency of the pulsation generator, and record the temperature of the heat exchanger inlet and outlet and the heat exchanger refrigerant. The frequency was controlled at $16.6 \mathrm{~Hz}, 20.6 \mathrm{~Hz}, 24.8 \mathrm{~Hz}$, and $28.4 \mathrm{~Hz}$, and a total of 8 sets of data were recorded. The second set of experiments controlled the frequency to $20 \mathrm{~Hz}$ and changed the heat medium flow. The inlet and outlet temperatures of the heat exchanger and the initial temperature of the refrigerant are the same as in the first set of tests. The flow of each group was $0.143 \mathrm{~L} / \mathrm{s}, 0.182 \mathrm{~L} / \mathrm{s}$, $0.222 \mathrm{~L} / \mathrm{s}$, and $0.286 \mathrm{~L} / \mathrm{s}$, and a total of 8 groups of data were recorded. 


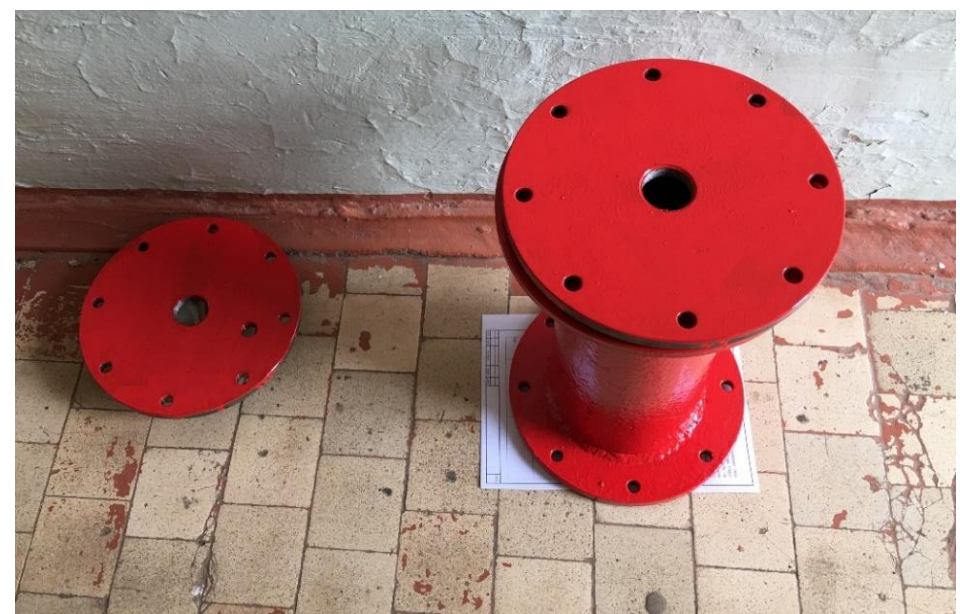

(a) Heat exchanger shell;

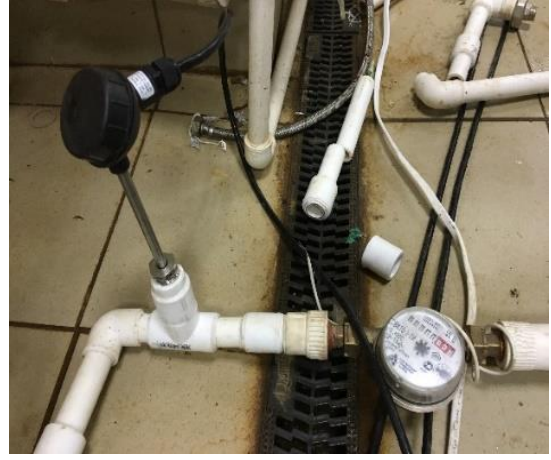

(b) Temperature sensor and flow meter;

Figure 1. Main components of heat exchanger.

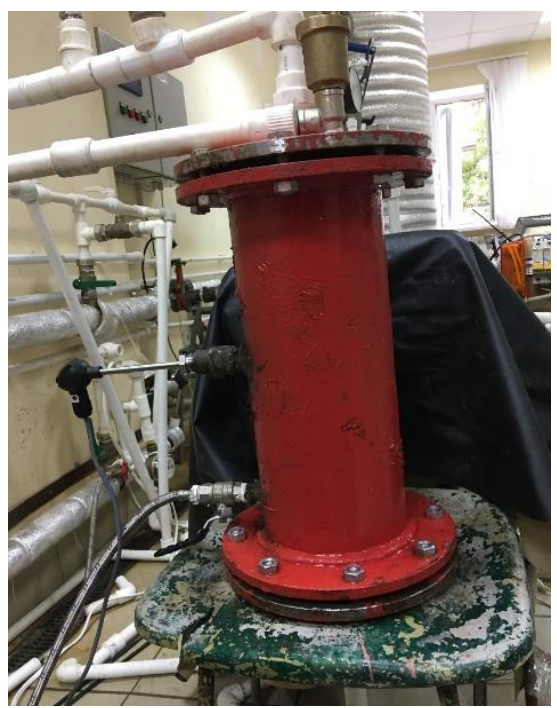

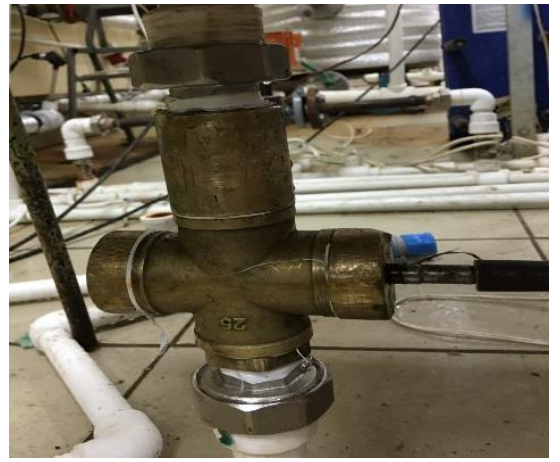

(c) Shocking valve.

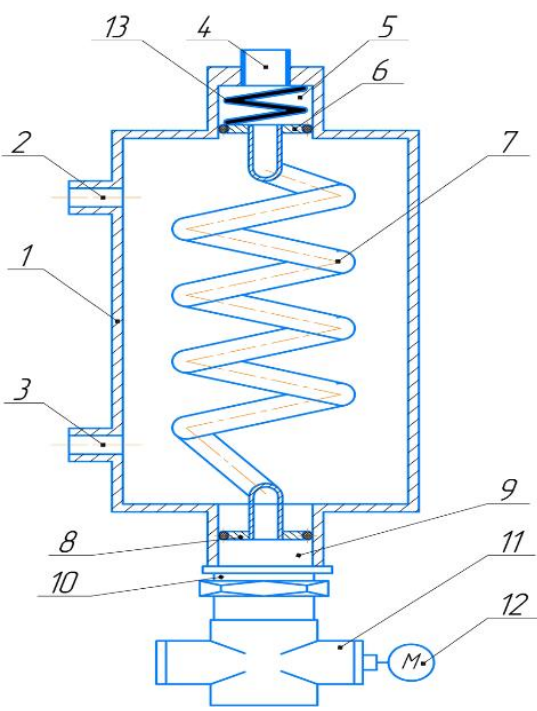

Figure 2. Installation principle of test equipment.

The working principle of the pulsation valve is as follows: the upper end of the component is connected to the outlet of the heat exchanger coil, and the lower end is connected to the hot water recovery pipe. The inner cam is connected to the motor through a metal rod on the right side, and the cam rotation drives the reciprocating motion of the inner piston (valve), thereby causing pulsation in 
the tube. The operating frequency of the pulsation generator can be controlled by controlling the motor speed. The speed is controlled by the frequency converter. At the end of the test, the data obtained is recorded in a table for further processing.

\section{Analysis of test results}

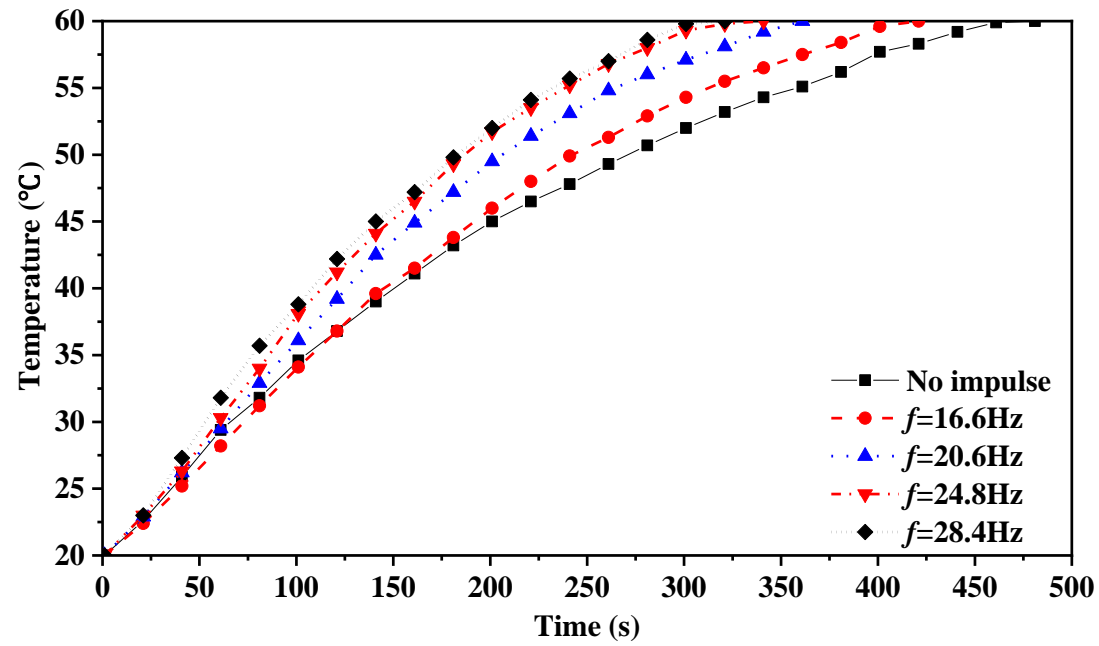

Figure 3. Temperature comparison at different frequency.

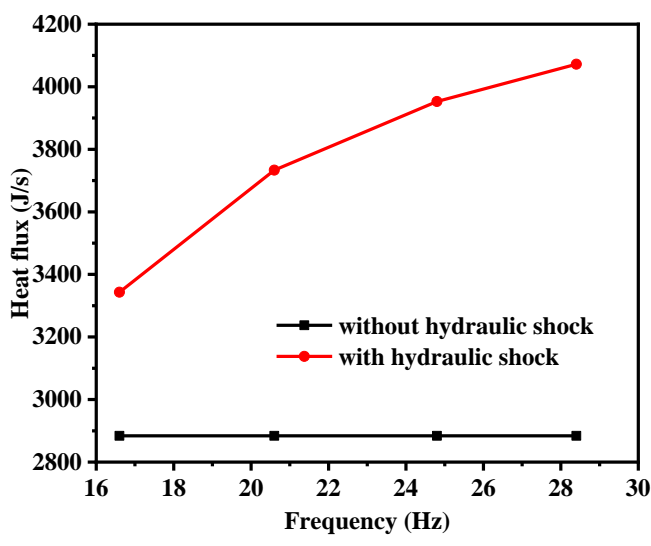

(a) heat flux of heat exchanger;

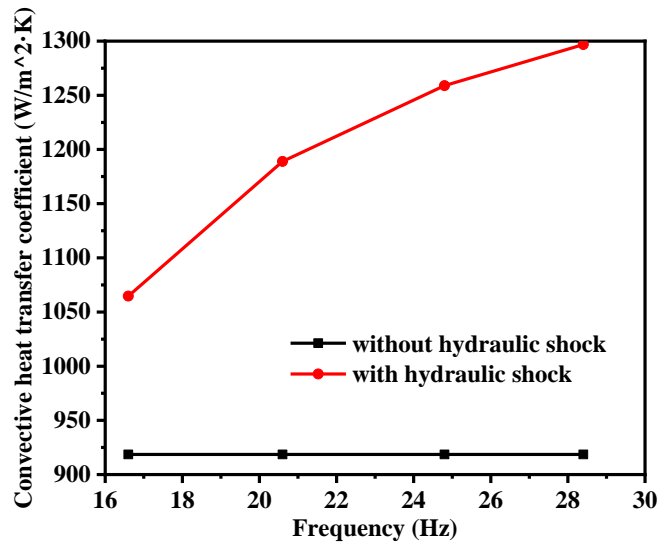

(b) convective heat transfer coefficient.

Figure 4. Heat flux and convective heat transfer coefficient of heat exchanger.

As shown in the figure 3 , in the event of pulse impact, the time required for the refrigerant to reach $60^{\circ} \mathrm{C}$ will be shorter and the heating rate will be accelerated. With the increase of frequency, the time needed for the refrigerant to reach $60^{\circ} \mathrm{C}$ is shorter and shorter, and the heating rate is faster and faster. When the pulsation frequency was $16.6 \mathrm{hz}$, it was 60 seconds less than when there was no pulsation. At the frequency of $20.6 \mathrm{hz}$, when pulsation impact occurs, the temperature change of the heat exchanger will be faster, which is $60 \mathrm{~s}$ faster than that at $16.6 \mathrm{hz}$. The pulsation rate was 20 seconds faster than $20.6 \mathrm{~Hz}$ at $24.8 \mathrm{~Hz}$, and the pulsation rate was 20 seconds faster than $24.8 \mathrm{~Hz}$ at $28.4 \mathrm{~Hz}$. Thus it can be seen that the speed of temperature change does not increase infinitely with the increase of the pulsation frequency. When the pulsation frequency is higher than $28.4 \mathrm{hz}$, a cutoff frequency will appear. When the pulsation frequency exceeds this frequency, the heat transfer velocity will not increase, but remain unchanged. 
As shown in Figure 4, when there is a pulsating shock, the heat flux between the heat exchanger and the refrigerant of the heat exchanger is higher than that without pulsation at four frequencies, and the convective heat transfer coefficient is the same. It can be seen from the curve trend in the figure that the higher the frequency, the larger the heat flow, and the larger the convective heat transfer coefficient. As the frequency increases, the increasing trend of heat flux and convective heat transfer coefficient slows down. It can be seen that the heat flux and convective heat transfer coefficient will not increase infinitely with the increase of the pulsation frequency, but there is a cut-off frequency. When the pulsation frequency reaches this frequency, the increase of the pulsation frequency will not continue to strengthen the heat transfer.

\section{Conclusion}

The purpose of this test is to generate a pulsating flow through a pulsation generator to enhance heat transfer around the heat exchanger.

Assess the integrity of the task solution:

The structure of coil heat exchanger is designed. The development and testing of experimental samples of pulsed disk heat exchangers were carried out. The effect of pulsating frequency on heat transfer efficiency was obtained.

During the development of the experimental device, the heat transfer efficiency was improved, the time loss of industrial production equipment was reduced, and the time cost was reduced.

Based on the data analysis, we can conclude that the heat transfer efficiency peaks around $28.4 \mathrm{~Hz}$, which means that the pulsation frequency is best controlled around $28.4 \mathrm{~Hz}$. When the heat exchange efficiency of each frequency is considered in the experiment, it can be said that the heat exchange efficiency increases as the frequency increases. As the flow increases, so does the amount of heat exchange. The heat transfer rate can be increased by increasing the flow.

It is worth noting that when the pulsation frequency is increased to $28.4 \mathrm{~Hz}$, the improvement in heat transfer efficiency is not so obvious. It can be inferred that within a certain frequency range, as the pulsation frequency increases, the heat transfer efficiency increases, and beyond this frequency, the heat transfer efficiency no longer increases or decreases. Therefore, it is necessary to find a suitable pulsation frequency according to the structure and characteristics of the heat exchange device, so as to achieve the effect of improving heat exchange efficiency, saving time and cost, and reducing energy consumption

\section{References:}

1. Wang, W. Q., Zhang, L. X., \& Yan, Y. A. N. (2007). Study on turbulence features near an oscillating curved wall. Journal of Hydrodynamics, 19(3), 255-263. https://doi.org/10.1016/S10016058(07)60057-2

2. Xu, Q. X., \& Shen, R. Y. (2008). Fluid-structure interaction of hydrodynamic damper during the rush into the water channel. Journal of Hydrodynamics, Ser. B, 20(5), 583-590. https://doi.org/10.1016/S1001-6058(08)60098-0

3. Qing, Y. A. N. G. (2003). WANG Ji sheng, WANG Li. Interaction of wind with fabric structures [J]. Spatial Structures, 1. (in Chinese).

4. Qing-shan, Y. A. N. G. (2006). LIU Rui-xia On aerodynamic stability of membrane structures [J]. Engineering Mechanics, 9. (in Chinese).

5. Yang, Q. S., Wu, Y., \& Zhu, W. L. (2008). Experimental study on the static interaction between membrane structures and air. China Civil Engineering Journal, 41(5), 19-25. (in Chinese). 
6. Shen, S. Z., \& Wu, Y. (2006). Research progress on fluid-solid interaction effect of windinduced vibration respond of membrane structure. Journal of Architecture and civil engineering (Chinese), 23, 1-9. (in Chinese).

7. Ortega-Casanova, J., \& Molina-Gonzalez, F. (2017). Axisymmetric numerical investigation of the heat transfer enhancement from a heated plate to an impinging turbulent axial jet via small vortex generators. International Journal of Heat and Mass Transfer, 106, 183-194. https://doi.org/10.1016/j.ijheatmasstransfer.2016.10.064

8. Staats, W. L., \& Brisson, J. G. (2015). Active heat transfer enhancement in air cooled heat sinks using integrated centrifugal fans. International Journal of Heat and Mass Transfer, 82, 189205. https://doi.org/10.1016/j.ijheatmasstransfer.2014.10.075

9. Yan, K., Hong, J., Zhang, J., Mi, W., \& Wu, W. (2016). Thermal-deformation coupling in thermal network for transient analysis of spindle-bearing system. International Journal of Thermal Sciences, 104, 1-12. https://doi.org/10.1016/j.ijthermalsci.2015.12.007

10. Mahmoudi, Y., \& Karimi, N. (2014). Numerical investigation of heat transfer enhancement in a pipe partially filled with a porous material under local thermal non-equilibrium condition. International Journal of Heat and Mass Transfer,68, 161-173. https://doi.org/10.1016/j.ijheatmasstransfer.2013.09.020

11. Defraeye, T., Blocken, B., \& Carmeliet, J. (2010). CFD analysis of convective heat transfer at the surfaces of a cube immersed in a turbulent boundary layer. International Journal of Heat and Mass Transfer, 53(1-3), 297-308. https://doi.org/10.1016/j.ijheatmasstransfer.2009.09.029

12. Chang, S. W., Chiang, K. F., \& Kao, J. K. (2012). Heat transfer in rotating spiral channel with two opposite planar walls roughened by skew ribs. International journal of thermal sciences, 56, 107-121. https://doi.org/10.1016/j.ijthermalsci.2012.01.018

13. Guo, C., Hu, X., Cao, W., Yu, D., \& Tang, D. (2013). Effect of mechanical vibration on flow and heat transfer characteristics in rectangular microgrooves. Applied thermal engineering, 52(2), 385-393. https://doi.org/10.1016/j.applthermaleng.2012.12.010

14. E Richardson, E. G., \& Tyler, E. (1929). The transverse velocity gradient near the mouths of pipes in which an alternating or continuous flow of air is established. Proceedings of the Physical Society, 42(1), 1. https://doi.org/10.1088/0959-5309/42/1/302

15. Uchida, S. (1956). The pulsating viscous flow superposed on the steady laminar motion of incompressible fluid in a circular pipe. Zeitschrift für angewandte Mathematik und Physik ZAMP, 7(5), 403-422. https://doi.org/10.1007/BF01606327

16. Havemann, H. A., \& Rao, N. N. (1954). Heat transfer in pulsating flow. Nature, 174(4418), 41-41.

17. Bergles, A. E. (1988). Some perspectives on enhanced heat transfer-second-generation heat transfer technology. https://doi.org/10.1115/1.3250612

18. Wang, X., \& Zhang, N. (2005). Numerical analysis of heat transfer in pulsating turbulent flow in a pipe. International Journal of Heat and Mass Transfer, 48(19-20), 3957-3970. https://doi.org/10.1016/j.ijheatmasstransfer.2005.04.011

19. Elshafei, E. A., Mohamed, M. S., Mansour, H., \& Sakr, M. (2008). Experimental study of heat transfer in pulsating turbulent flow in a pipe. International Journal of Heat and Fluid Flow, 29(4), 1029-1038. https://doi.org/10.1016/j.ijheatfluidflow.2008.03.018

\section{Список литературы:}

1. Wang W., Zhang L., Yan Y. A. N. Study on turbulence features near an oscillating curved wall // Journal of Hydrodynamics. 2007. Vol. 19. №3. P. 255-263. https://doi.org/10.1016/S10016058(07)60057-2 
2. Xu Q., Shen R. Fluid-structure interaction of hydrodynamic damper during the rush into the water channel // Journal of Hydrodynamics, Ser. B. 2008. Vol. 20. №5. P. 583-590. https://doi.org/10.1016/S1001-6058(08)60098-0

3. Qing Y. shan, WANG Ji sheng, WANG Li. Interaction of wind with fabric structures $[\mathrm{J}] / /$ Spatial Structures. 2003. Vol. 1. (in Chinese).

4. Qing-shan Y., Liu Rui-xia On aerodynamic stability of membrane structures [J] // Engineering Mechanics. 2006. Vol. 9. (in Chinese).

5. Yang Q., Wu Y., Zhu W. Experimental study on the static interaction between membrane structures and air // China Civil Engineering Journal. 2008. Vol. 41. №5. P. 19-25. (in Chinese).

6. Shen S. Z., Wu Y. Research progress on fluid-solid interaction effect of wind-induced vibration respond of membrane structure // Journal of Architecture and civil engineering (Chinese). 2006. Vol. 23. P. 1-9. (in Chinese).

7. Ortega-Casanova J., Molina-Gonzalez F. Axisymmetric numerical investigation of the heat transfer enhancement from a heated plate to an impinging turbulent axial jet via small vortex generators // International Journal of Heat and Mass Transfer. 2017. Vol. 106. P. 183-194. https://doi.org/10.1016/j.ijheatmasstransfer.2016.10.064

8. Staats W. L., Brisson J. G. Active heat transfer enhancement in air cooled heat sinks using integrated centrifugal fans // International Journal of Heat and Mass Transfer. 2015. Vol. 82. P. 189205. https://doi.org/10.1016/j.ijheatmasstransfer.2014.10.075

9. Yan K. et al. Thermal-deformation coupling in thermal network for transient analysis of spindle-bearing system // International Journal of Thermal Sciences. 2016. Vol. 104. P. 1-12. https://doi.org/10.1016/j.ijthermalsci.2015.12.007

10. Mahmoudi Y., Karimi N. Numerical investigation of heat transfer enhancement in a pipe partially filled with a porous material under local thermal non-equilibrium condition // International Journal of Heat and Mass Transfer. 2014. Vol. 68. P. 161-173. https://doi.org/10.1016/j.ijheatmasstransfer.2013.09.020

11. Defraeye T., Blocken B., Carmeliet J. CFD analysis of convective heat transfer at the surfaces of a cube immersed in a turbulent boundary layer // International Journal of Heat and Mass Transfer. 2010. Vol. 53. №1-3. P. 297-308. https://doi.org/10.1016/j.ijheatmasstransfer.2009.09.029

12. Chang S. W., Chiang K. F., Kao J. K. Heat transfer in rotating spiral channel with two opposite planar walls roughened by skew ribs // International journal of thermal sciences. 2012. Vol. 56. P. 107-121. https://doi.org/10.1016/j.ijthermalsci.2012.01.018

13. Guo C. et al. Effect of mechanical vibration on flow and heat transfer characteristics in rectangular microgrooves // Applied thermal engineering. 2013. Vol. 52. №2. P. 385-393. https://doi.org/10.1016/j.applthermaleng.2012.12.010

14. Richardson E. G., Tyler E. The transverse velocity gradient near the mouths of pipes in which an alternating or continuous flow of air is established // Proceedings of the Physical Society. 1929. Vol. 42. №1. P. 1. https://doi.org/10.1088/0959-5309/42/1/302

15. Uchida $S$. The pulsating viscous flow superposed on the steady laminar motion of incompressible fluid in a circular pipe // Zeitschrift für angewandte Mathematik und Physik ZAMP. 1956. Vol. 7. №5. P. 403-422. https://doi.org/10.1007/BF01606327

16. Havemann H. A., Rao N. N. N. Heat transfer in pulsating flow // Nature. 1954. Vol. 174. №4418. P. 41-41.

17. Bergles A. E. Some perspectives on enhanced heat transfer-second-generation heat transfer technology. 1988. https://doi.org/10.1115/1.3250612 
18. Wang X., Zhang N. Numerical analysis of heat transfer in pulsating turbulent flow in a pipe // International Journal of Heat and Mass Transfer. 2005. Vol. 48. №19-20. P. 3957-3970. https://doi.org/10.1016/j.ijheatmasstransfer.2005.04.011

19. Elshafei E. A. M. et al. Experimental study of heat transfer in pulsating turbulent flow in a pipe // International Journal of Heat and Fluid Flow. 2008. Vol. 29. №4. P. 1029-1038. https://doi.org/10.1016/j.ijheatfluidflow.2008.03.018

Ссылка для циитирования:

Liu Z., Levtsev A., Zhou Y. Experimental Study on a Pulsation-enhanced Heat Transfer Device // Бюллетень науки и практики. 2020. Т. 6. №4. С. 243-251. https://doi.org/10.33619/2414-2948/53/28

Cite as (APA):

Liu, Z., Levtsev, A., \& Zhou, Y. (2020). Experimental Study on a Pulsation-enhanced Heat Transfer Device. Bulletin of Science and Practice, 6(4), 243-251. https://doi.org/10.33619/2414$2948 / 53 / 28$ 